\title{
炭素材料の機能化
}

坪川紀夫·遠藤 剛*

(平成元年 8 月 14 日受理)

\section{Functionalization of Carbon Materials}

\author{
Norio Tsubokawa and Takeshi Endo*
}

\begin{abstract}
Faculty of Engineering, Niigata University, 8050, Ikarashi
2-nocho, Niigata 950-21, Japan

*Research Laboratory of Resources Utilization, Tokyo Institute of Technology, Nagatsuta, Midori-ku, Yokohama 227, Japan
\end{abstract}

To modify chemically the surface of carbon materials, such as carbon black, graphite powder, carbon fiber, and carbon whisker (vapor-growth carbon fiber), the incorporation of functional groups onto these surface was reviewed.

Carbon materials having reactive groups such as acyl chloride, acyl azide, and active ester groups can be used for the grafting of hydroxyl- or amino-capped commercial available polymers. The grafting method by the reaction of reactive groups on carbon material with polymers enables us to control the molecular weight of grafted polymer chain.

The incorporation of initiating groups such as azo, peroxyester, acylium perchlorate, and potassium carboxylate groups, onto carbon surface could be succeeded and their applications to the graft polymerization and copolymerization of various monomers were attempted to obtain polymer-grafted carbon blacks with a higher percentage of grafting.

Furthermore, it was demonstrated that carbon materials, especially carbon black having much oxygen containing groups, acted as not only curing agent of urethaneprepolymer, epoxy resins, and polyfunctional spiro ortho ester resins but also electron transfer catalyst of two-phase systems (aqueous-organic phase) in dehydrogenation of hydrazo nitriles.

KEYWORDS: Functionalization, Reactive carbon material, Graft polymerization, Modification of surface, Curing agent

\section{1. 緒言}

一般に, 炭素材料は耐熱性, 耐薬品性, 耐候性, 導電 性, 低熱膨脹性, 軽量などといった優れた特性を有して おり，“宇宙から心臟の中まで”之いわれるほよ゙，現 在広く利用されている。ところで, このような炭素材料
は単独で使用されることは少なく, 多くの場合，高分子 との複合系で使用されている。したがって, 炭素系複合 高分子材料を設計するに当たって，炭素材料とマトリッ クス（高分子）とが接している界面の制御が重要な問題 となっている。

このような問題を解決するため, 炭素材料表面の改質
新潟大学工学部化学システム工学科 : テ 950-21 新潟市 五十嵐二の町 8,050
*東京工業大学資源化学研究所 : $=227$ 横浜市緑区長津 田 4,259 
に関して，様々な角度から検討されてきた。たとえば， 化学的改質法としては, 酸化処理, 表面活性剂処理, 力 ップリング剂処理，グラフト化処理などが広く行われて いる。さらに，物理的表面改質法としては，プラズマ処 理やスパッタエッチング処理などが試みられている。

また, 最近では, 炭素材料の表面構造や表面官能基を 精密に設計することにより, 炭素材料が持つ特性を著し く向上させたり，新しい機能を付与させることが可能に なってきた。

著者らあ，炭素材料表面の改質と機能化を目的に，表 面の含酸素官能基をベースとする各種官能基の導入とそ れらを用いるグラフト重合について検討してきた。

本稿では，カーボンブラック，微粒子グラファイト， 炭素繊維, 及びカーボンウイスカー（気相生長炭素繊維） などの炭素材料表面の機能設計について概説する。

\section{2. 炭素材料表面の含酸素官能基}

炭素材料表面には，一般に，フェノール性水酸基，力 ルボキシル基, 及びキノン型酸素などの含酸素官能基が 存在する ${ }^{2)}$ 。当然，乙れらの表面官能基の数は炭素材料 の種類により著しく異なる。Table 1 亿，その一例とし て, カーボンブラック，グラファイト，炭素繊維，及び カーボンウイスカー（気相生長炭素繊維）表面の官能基 の数を示した。また，カーボンブラックを取上げてみて あ，製造法により表面性状が異なっており，チャンネル ブラック表面には，数多くの官能基があるのに対して， ファーネスブラックやアセチレンブラック表面の官能基 は少ない。また，グラファイトや炭素繊維表面の官能基 も極端に少ないので，表面機能設計に当たっては有機合 成に基づいた工夫が必要になる。

Fig. 1 亿は，炭素材料表面のフェノール性水酸基や力 ルボキシル基を足場とした各種官能基の導入反応をまと

Table 1 Surface functional groups on carbon materials.

\begin{tabular}{lclllc}
\hline Carbon material & $\begin{array}{c}\text { BET surface } \\
\text { area }\left(\mathrm{m}^{2} / \mathrm{g}\right)\end{array}$ & $\begin{array}{c}\mathrm{COOH} \\
(\mathrm{mmol} / \mathrm{g})\end{array}$ & $\begin{array}{c}\mathrm{OH} \\
(\mathrm{mmol} / \mathrm{g})\end{array}$ & $\begin{array}{c}\mathrm{C}=\mathrm{O} \\
(\mathrm{mmol} / \mathrm{g})\end{array}$ \\
\hline Carbon black & & & & \\
$\quad$ Neospectra II & 906 & 0.40 & 0.24 & 0.92 \\
Philblack O $^{\mathrm{b}}$ & 79.6 & 0 & 0.02 & 0.18 \\
$\quad \begin{array}{l}\text { Denkablack } \\
\text { G }\end{array}$ & 65 & 0 & 0.02 & 0.01 \\
Graphite & - & 0 & 0.01 & 0.08 \\
Carbon fiber & - & 0.002 & 0.001 & - \\
Carbon whisker & - & 0.08 & 0.06 & 0.09 \\
\hline
\end{tabular}

${ }^{\mathrm{a}}$ Channel black. ${ }^{\mathrm{b}}$ Furnace black. ${ }^{\mathrm{c}}$ Acetylene black.

めて示した。以下に，乙れらの官能基を用いる炭素材料 の機能化について最近の報告を中心に紹介する。

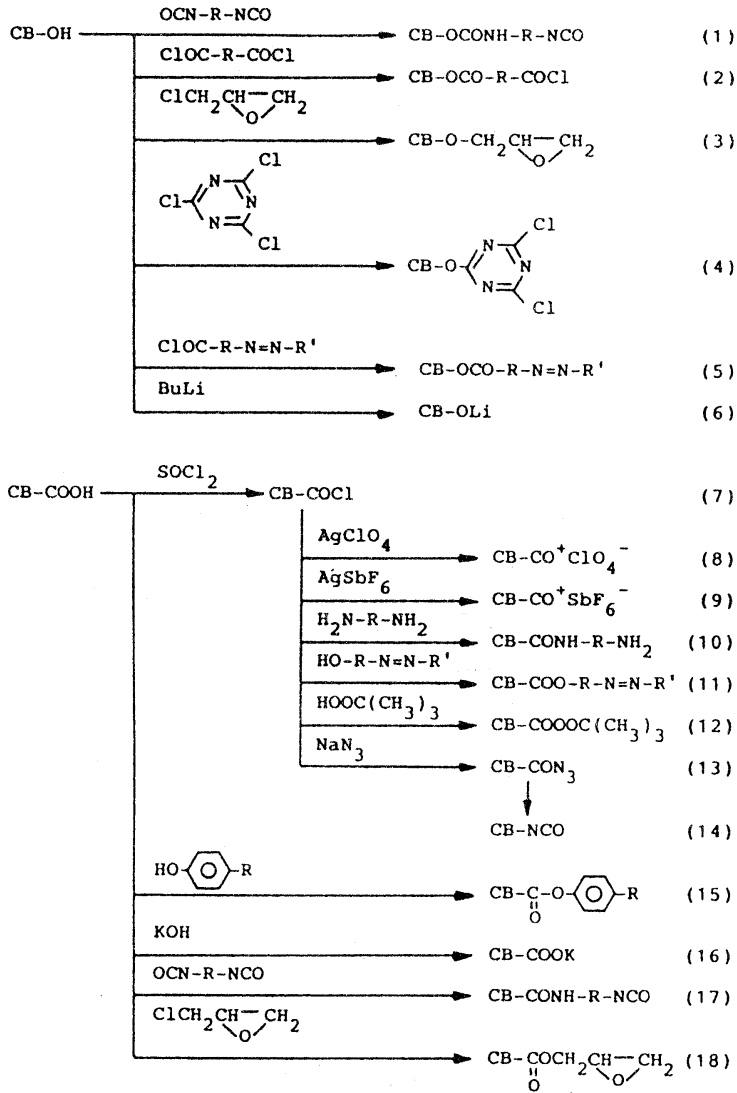

Fig. 1 Incorporation of functional groups onto carbon materials $(\mathrm{CB})$.

\section{3. 反応性炭素材料の設計}

\section{1 反応性カーボンブラック}

高反応性の官能基を導入したカーボンブラック（こて では，反応性カーボンブラックという）を用いると，水 酸基あるいはアミノ基を持つ汎用高分子のグラフトが可 能である。したがって，カーボンブラック表面へのイソ シアナート (NCO) 基 (式 1，14，17）吕やそのプレカーサ 一であるアシルアジド $\left(\mathrm{CON}_{3}\right)$ 基 (式 13) ${ }^{4}$ ，酸クロリ ド $(\mathrm{COCl})$ 基 (式 2,7$)^{5}$ ，エポキシ基 $(\text { 式 } 3,18)^{6)}$ ，シ アヌルクロリド基 (式 4) ${ }^{7)}$ ，さらには活性エステル基(式 $15)^{8)}$ の導入反応が検討されている。

反応性の炭素材料を設計するにあたっては，できるだ け高反応性の官能基を導入するてとが望ましいが，NCO 基を導入したものは，保存中に空気中の水分などと反応 して失活するので取扱いに注意を要する ${ }^{3)}$ 。

\section{2 反応性炭素材料を用いるグラフト反応}

反応性カーボンブラックを用いるグラフト反応の一例 として, Table 2 に, $\mathrm{CON}_{3}$ 基を導入したカーボンブラッ クと各種のポリマーとのグラフト反応（式19）を行った結 
Table 2 Grafting of various polymers by use of reactive carbon black having $\mathrm{CON}_{3}$ groups $\left(\mathrm{CB}-\mathrm{CON}_{\mathbf{3}}\right)^{\mathrm{a}}$

\begin{tabular}{lcccc}
\hline Polymer & Mn $\times 10^{-3}$ & $\begin{array}{c}\text { Solvent } \\
(\mathrm{ml})\end{array}$ & $\begin{array}{c}\text { Temperature } \\
\left({ }^{\circ} \mathrm{C}\right)\end{array}$ & $\begin{array}{c}\text { Grafting } \\
(\%)\end{array}$ \\
\hline PBG & 2.8 & - & 80 & 30.2 \\
PPG & 2.0 & - & 130 & 21.7 \\
PEG & 6.0 & - & 130 & 29.7 \\
SDO & 1.0 & - & 130 & 30.7 \\
SDA & 3.0 & 7.0 & 80 & 49.7 \\
PEI & 22 & 7.0 & 80 & 81.7 \\
PVA & 22 & 7.0 & 130 & 32.2 \\
Starch & - & 7.0 & 130 & 23.0 \\
\hline
\end{tabular}

${ }^{\mathrm{a}} \mathrm{CB}-\mathrm{CON}_{3}, 0.25 \mathrm{~g}$; polymer, $2.5 \mathrm{mmol} ; 20 \mathrm{~h}$.

${ }^{\mathrm{b}}$ Dimethyl sulfoxide.

PBG, Poly (butadiene glycol);

PPG, Poly (propylene gly col); PEG, Poly (ethylene glycol);

SDO, Silicone diol; SDA, Silicone diamine;

PEI, Polyethyleneimine; PVA, Poly (vinyl alcohol).

$\mathrm{CB}-\mathrm{CON}_{3}+\mathrm{HO} \sim \mathrm{OH} \rightarrow \mathrm{CB}-\mathrm{NHCOO} \sim \mathrm{OH}$

$\mathrm{CB}-\mathrm{CON}_{3}+\mathrm{H}_{2} \mathrm{~N} \sim \mathrm{NH}_{2} \rightarrow \mathrm{CB}-\mathrm{NHCONH} \sim \mathrm{NH}_{2}$

果を示す。な抢，乙れらのポリマーは，ウレタンあるい

は，尿素結合を介して粒子表面へグラフトする。

さらに, 反応性のカーボンウイスカーの設計も可能で

あり, 各種のポリマーのグラフト反応に利用できる。

\section{3 グラフト反応に及ぼす分子量の効果}

と乙ろで，乙のようなグラフト反応には，用いるポリ マーの分子量が大きく影響を及ぼすととが見出されてい る。Fig. 2 亿, シアメルクロリド基を導入したカーボン

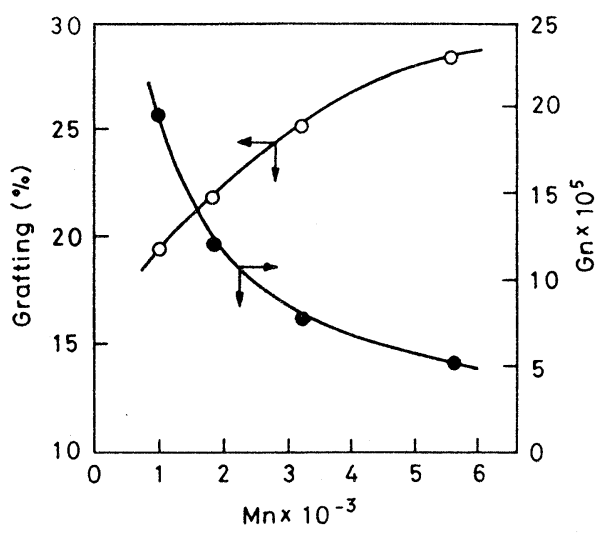

Fig. 2 Effect of molecular weight (Mn) of SDO on the grafting by the reaction of cyanuric chloride groups with SDO. Gn: the number of grafted polymer.
ブラックとシリコーンジオール（SDO）とのグラフト反 応に及ぼすSDOの分子量の影響を調べた結果を示した。 $\mathrm{SDO}$ 0分子量が大きくなると, グラフト率は增大するが, 粒子表面へグラフトしたポリマー鎖の数 $\left(\mathrm{G}_{n}\right)$ はかえっ て減少する ${ }^{7)}$ 。乙こで, $\log \mathrm{M}_{n}$ と $\log \mathrm{G}_{n}$ との関係をプ ロットすると直線関係が得られ， $\mathrm{G}_{n}$ と $\mathrm{SDO} の \mathrm{M}_{n}$ との 関係は式 20 で表わされる。

$$
\mathrm{G}_{n}=4.27 \times 10^{-2} \mathrm{M}_{n}{ }^{-0.78}
$$

したがって，式20を用いると SDO の $\mathrm{M}_{n}$ から，最大 のグラフト率が予想できるととになる。乙れと類似の関 係は， $\mathrm{CON}_{3}$ 基やエポキシ基などを導入したカーボンブ ラックを用いる各種ポリマーのグラフト反応に扔いても

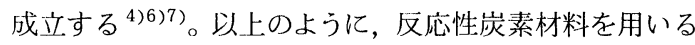
と，その表面へグラフトするポリマーの分子量が規制で きるという大きな特徴があり, 反応性炭素材料の利用は 表面グラフト鎖の機能設計を進めるにあたり有効な手段 となるであろう。

\section{4. 重合開始基を持つ炭素材料の設計}

\section{1 ラジカル重合開始基の導入}

カーボンブラックなどの炭素材料は，遊離ラジカルを 持っているが，その芳香族共役系により共鳴安定化して いるため, ラジカル重合を開始する能力はなく, 逆にラ ジカル重合禁止剂として作用する ${ }^{9)}$ 。したがって, 炭素 材料表面からラジカルグラフト重合を開始させるために は，その表面へ新たな活性ラジカルを導入する必要があ る。

(a) パーオキシエステル基を用いるグラフト重合 四十宮らは，炭素䋐維表面へ導入したパーオキシエス テル基を用いる繊維表面へのビニルモノマーのラジカルグ ラフト重合に成功した ${ }^{10)}$ 。

一方，著者らは，パーオキシエステル基を導入したカ 一ボンブラック（式 12）を重合開始剤に用いるビニルモ ノマーのラジカルグラフト重合について検討した ${ }^{11)}$ (Table 3)。Table 3 からわかるように, e值が正のモノマーの 系では, グラフト重合が効率良く進行するのに対して, $e$ 值が負のモノマーの系ではグラフト重合がほとんど進 行しない。乙れは開始剤にパーオキサイドを用いる。 $e$ 值が負のモノマーの重合系では, カーボンブラックが強 力な重合遅延剂として作用するためである ${ }^{12)}$ 。したがっ て, パーオキシエステル基を導入したカーボンブラック によるグラフト重合は， $e$ 值が正のモノマーに限られる ${ }^{13)}$ 。

(b) アゾ基を用いるグラフト重合

カーボンブラック表面へのアゾ基の導入は, 式 5 と11 に上るほか, 反応性基を持つアゾ開始剤（カルボキシル 
Table 3 Polymerization of various monomers initiated by carbon black having peroxyester groups (CB-POE).

\begin{tabular}{lrrr}
\hline Monomer & e-Vaue & $\begin{array}{c}\text { Conversion } \\
(\%)\end{array}$ & $\begin{array}{c}\text { Grafting } \\
(\%)\end{array}$ \\
\hline$N$-Vinyl-2-pyrrolidone & -1.14 & 0.9 & 9.8 \\
Styrene & -0.80 & 0.5 & 5.2 \\
4-Vinylpyridine & -0.28 & 0.9 & 7.6 \\
Vinyl acetate & -0.22 & 0.2 & 2.3 \\
2-Hydroxyethyl methacrylate & 0.20 & 2.7 & 36.9 \\
Methyl methacrylate & 0.40 & 3.8 & 45.6 \\
Glycidyl methacrylate & 0.57 & 5.6 & 86.7 \\
Methyl vinyl ketone & 0.68 & 2.4 & 33.4 \\
Acrylic acid & 0.77 & 20.9 & 124.4 \\
Acrylonitrile & 1.20 & 10.8 & 77.5 \\
\hline
\end{tabular}

CB-POE, $0.30 \mathrm{~g}$; monomer, $10.0 \mathrm{ml} ; 70^{\circ} \mathrm{C}$

基やイミダゾリン環を持つアゾ開始剂が数多く市販され ている）と粒子表面のイソシアナート基やエポキシ基と の反応によってあ行わ机る ${ }^{14)}$ 。Table 4には，アゾ基を 導入したカーボンブラックによる $e$ 值の異なるモノマー の重合を検討した結果を示した。乙の系では， $e$ 值の正 負に関係なくいずれのモノマーの重合あ開始されること がわかる（式 21）。な拉, 重合系では, 当然非グラフト

$$
\mathrm{CB} \sim \mathrm{R}-\mathrm{N}=\mathrm{N}-\mathrm{R}^{\prime}
$$

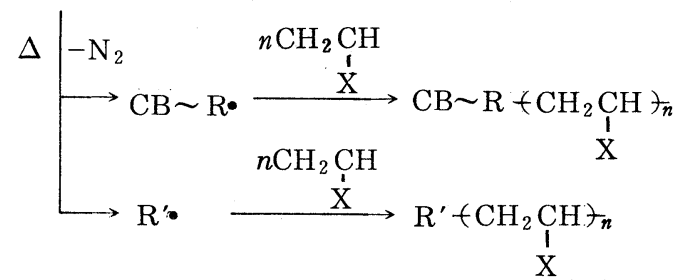

Table 4 Polymerization of various monomers initiated by carbon black having azo groups (CB-Azo).

\begin{tabular}{lrrc}
\hline Monomer & e-Value & $\begin{array}{c}\text { Conversion } \\
(\%)\end{array}$ & $\begin{array}{c}\text { Grafting } \\
(\%)\end{array}$ \\
\hline$N$-Vinyl-2-pyrrolidone & -1.14 & 2.6 & 74.3 \\
Styrene & -0.80 & 2.0 & 28.5 \\
4-Vinylpyridine & -0.28 & 10.3 & 79.9 \\
Vinyl acetate & -0.22 & 2.3 & 20.5 \\
2-Hydroxyethyl methacrylate & 0.20 & 1.7 & 24.0 \\
Methyl methacrylate & 0.40 & 4.7 & 40.0 \\
Glycidyl methacrylate & 0.57 & 10.6 & 87.5 \\
Methyl vinyl ketone & 0.68 & 4.6 & 35.2 \\
Acrylic acid & 0.77 & 6.2 & 64.8 \\
Acrylonitrile & 1.20 & 13.1 & 76.2 \\
\hline
\end{tabular}

CB-Azo, $0.30 \mathrm{~g}$; monomer, $10.0 \mathrm{ml} ; 70^{\circ} \mathrm{C}$.
ポリマー（ホモポリマー）の生成む伴うが，グラフト率 の大きなあのが得られている。

\section{2 カチオン重合開始基の導入}

\section{(a) カルボキシル基によるカチオングラフト}

炭素材料表面のカルボキシル基は, 隣接基の影響で大 きな酸性度を有しているため ${ }^{15)}, N$-ビニルカルバゾー ルや $N$-ビニルー2 -ピロリドンなどのカチオン重合を開 始する能力を持ち, 生成するポリマーの一部が炭素材料 表面へグラフトする (式 22) ${ }^{16)-19) 。 T a b l e ~} 5$ には，カー

$$
\begin{gathered}
\mathrm{CB}-\mathrm{COOH}+{ }_{n} \mathrm{CH}_{2} \mathrm{CH} \longrightarrow \\
\mathrm{X} \\
\mathrm{CB}-\mathrm{COO}-\mathrm{CH}_{2} \mathrm{CH}{ }_{n-1}-\mathrm{CH}-\mathrm{CH}_{3} \\
\stackrel{\mathrm{I}}{\mathrm{X}} \stackrel{\mathrm{X}}{\longrightarrow}
\end{gathered}
$$

ボンブラックによるビニルモノマーのカチオン重合開始 能力を検討した結果を示した。乙机から粒子表面のカル ボキシル基には, $e$ 值がー0.800以下のビニルモノマーの カチオン重合を開始する能力があるととがわかる。

さらに最近，カーボンブラック表面のカルボキシル基 により, スピロオルトエステル (SOE) 類 ${ }^{20)}$, スピロオ ルトカーボナート (SOC) 類 ${ }^{21)}$ ，あるいはビシクロオル トエステル (BOE) 類 ${ }^{22)}$ などのいわゆる非収縮モノマー のカチオン開環異性化重合が開始され，対応するポリマ

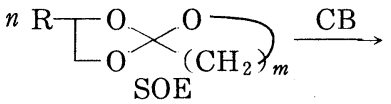

$$
\begin{aligned}
& \mathrm{CB}-\mathrm{COG}\left[\left(\mathrm{CH}_{2}\right)_{m} \mathrm{COOCHCH}_{\substack{l \\
\mathrm{O}}}\right]_{n}-\mathrm{H}
\end{aligned}
$$

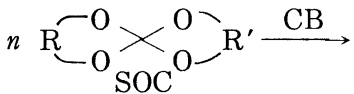

$$
\begin{aligned}
& \left.\mathrm{CB}-\mathrm{COO}-\mathrm{R}-\mathrm{O}-\mathrm{H}_{\mathrm{O}}^{\mathrm{C}}-\mathrm{O}-\mathrm{R}^{\prime}-\mathrm{O}\right]_{n} \mathrm{H}
\end{aligned}
$$

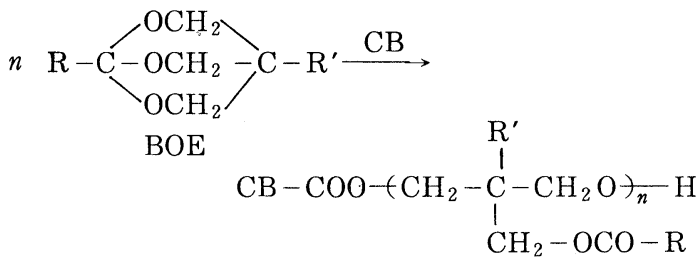

一が粒子表面へグラフトするととも見出された（式 23）。 Fig. 3 K，カーボンブラックによる SOE の重合結果を 示した。

また，カーボンブラック表面のカルボキシル基は, 2オキサゾリン類の開環重合を開始し，粒子表面へ曱漞媒 
Table 5 Initiating activity of carbon black for the cationic polymerization of various monomers.

\begin{tabular}{lcc}
\hline Monomer & e-Value & Polymerization \\
\hline Isobutyl vinyl ether & -1.77 & 0 \\
$N$-Vinylcarbazole & -1.40 & 0 \\
$\alpha$-Methylstyrene & -1.27 & 0 \\
$n$-Butyl vinyl ether & -1.20 & 0 \\
Ethyl vinyl ether & -1.17 & 0 \\
$N$-Vinyl-2-pyrrolidone & -1.14 & $\circ$ \\
Indene & -1.03 & 0 \\
2-Methyl-1-propene & -0.96 & Dimer 15) \\
Acenaphthylene & -0.80 & 0 \\
Styrene & -0.80 & $\mathrm{X}$ \\
2-Vinylphridine & -0.50 & $\times$ \\
4-Vinylpyridine & -0.28 & $\mathrm{X}$ \\
\hline
\end{tabular}

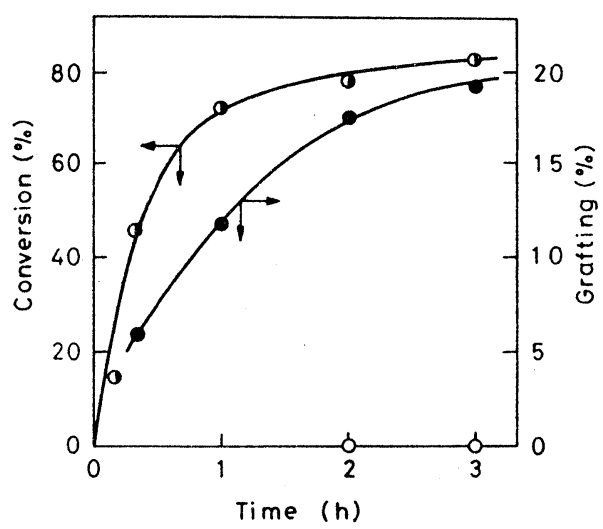

Fig. 3 Cationic polymerization of SOE initiated by carbon black. Carbon black, $0.30 \mathrm{~g}$; SOE, $0.02 \mathrm{~mol} ; 70^{\circ} \mathrm{C}$.

๑, •: in the presence of carbon black; $0:$ in the absence of carbon black.

性のポリオキサゾリンがグラフトする ${ }^{23)}$ 。

(b) $\mathrm{CO}^{+} \mathrm{ClO}$ - 基を用いるカチオングラフト

炭素材料表面のカルボキシル基はカチオン重合開始能 力を持つ $\mathrm{CO}^{+} \mathrm{ClO}_{4}^{-}$基（式 8) や $\mathrm{CO}^{+} \mathrm{SbF}_{6}^{-}$基 (式 9)へ と誘導できる。Fig.4 亿は, カーボンブラック表面へ導 入した $\mathrm{CO}^{+} \mathrm{ClO}_{4}^{-}$基によるスチレンのグラフト重合（式 24）に及ぼす重合温度の影響を示した ${ }^{24)}$ 。なお，てのよ<smiles>[X]CC=CCC([X])[C+]([O-])[O-]</smiles>

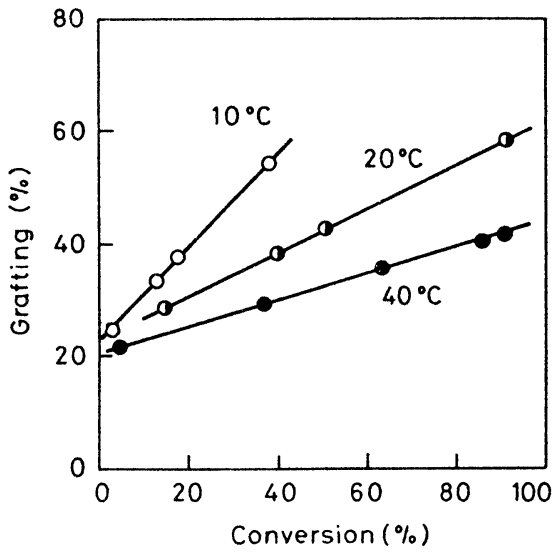

Fig. 4 Effect of temperature on the grafting of polystyrene initiated by $\mathrm{CO}^{+} \mathrm{C} 0_{4}{ }^{-}$ groups on carbon black. Pretreatment: CB-CO ${ }^{+} \mathrm{C} \mathrm{C}_{4}{ }^{-}, 0.30 \mathrm{~g} ; \mathrm{AgClO}_{4}, 0.20 \mathrm{~g}$; nitrobenzene, $5.0 \mathrm{ml}$; r.t.; $48 \mathrm{~h}$.

Polymerization: styrene, $10,0 \mathrm{ml}$.

$$
\begin{aligned}
& n \quad \underset{\left.\mathrm{CH}_{2}\right)_{m}}{\mathrm{O}} \mathrm{C}=\mathrm{O} \stackrel{\mathrm{CB}-\mathrm{CO}^{+} \mathrm{ClO}_{4}^{-}}{\longrightarrow} \\
& \mathrm{CB}-\mathrm{CO}\left[\mathrm{O}\left(\mathrm{CH}_{2}\right)_{{ }_{m}} \underset{\mathrm{O}}{\mathrm{C}}\right]_{n-1} \mathrm{O}\left(\mathrm{CH}_{2}\right)_{{ }_{m}} \underset{\|}{\mathrm{C}} \mathrm{C}^{+} \mathrm{ClO}_{4}^{-} \\
& n \stackrel{\left.\mathrm{CH}_{2}\right)_{m} \mathrm{O}}{\mathrm{CB}-\mathrm{CO}^{+} \mathrm{ClO}_{4}^{-}} \\
& \mathrm{CB}-\mathrm{CO}-\left[\mathrm{O}\left(\mathrm{CH}_{2}\right)_{m}\right]_{n-1} \stackrel{+}{\mathrm{O}} \longrightarrow\left(\mathrm{CH}_{2}\right)_{m} \mathrm{ClO}_{4}^{-}
\end{aligned}
$$

$$
\begin{aligned}
& n \overbrace{\mathrm{O}}^{\mathrm{O}} \stackrel{\mathrm{CB}-\mathrm{CO}^{+} \mathrm{ClO}_{4}^{-}}{\longrightarrow} \\
& \mathrm{CB}-\mathrm{CO}-\left(\mathrm{OCH}_{2}\right)_{3 n-3} \stackrel{+}{\mathrm{O}_{-}^{-}} \underbrace{\mathrm{O}}_{\mathrm{O}}>\mathrm{ClO}_{4}^{-}
\end{aligned}
$$

うな重合系では重合温度が高くなると, 重合速度は速く なるが，生長鎖の連鎖移動反応が活発になるため，グラ フト率は逆に低下する。

さらに，粒子表面の $\mathrm{CO}^{+} \mathrm{ClO}_{4}^{-}$基を開始剤に用いると，

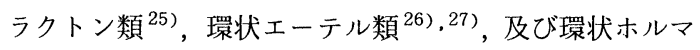
ール ${ }^{28)}$ の開環グラフト重合が可能になる（式 24）。

\section{3 アニオン重合開始基の導入}

\section{(a) COOK 基を用いるアニオングラフト}

炭素材料表面のカルボキシル基は水酸化カリウムで処 理すると容易に COOK 基に変換できる (式 16)。著者ら は, カーボンブラック表面へ導入した COOK 基により, 
$\beta$-プロピオラクトンのアニオン開環グラフト重合が開 始されることを見出した ${ }^{29)}$ 。

さらに, COOK 基を導入したカーボンブラック ${ }^{30)}$ ，炭 素繊維 ${ }^{31)}$ ，あるいはカーボンウイスカーは ${ }^{32)}$, エポキシ ドと環状酸無水物とのアニオン開環交互共重合を開始す る能力を持っており，てのような系では，構造の異なる 様々なポリエステルが炭素材料表面へグラフトする（式 25)。Table 6 には, 炭素繊維表面への各種ポリエステ ルのグラフト反応を行ったときの結果を示した。エポキ

$n$

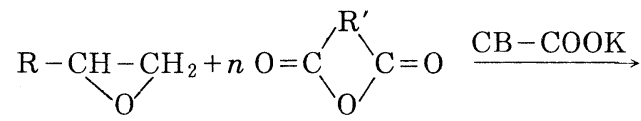<smiles>[R10]O[R]C(=O)OC([R])CC(=O)O[B]</smiles>

シドとしてスチレンオキシド $(\mathrm{SO})$, グリシジルフェニル エーテル (GPE), エピクロルヒドリン $(\mathrm{ECH})$, 及びグ リシジルメタクリレート (GMA)を, 環状酸無水物とし て, 無水コハク酸 $(\mathrm{SAn})$, 無水マレイン酸 $(\mathrm{MAn})$, 及 び無水フタル酸 (PAn) が用いられている。Table 6 の 結果は，モノマーを適当に選択すると，主鎖あるいは側 鎖に様々な機能基を持つポリエステルが炭素材料表面へ グラフトできることを示している。

たとえば，GMA と PAn との共重合で得られる不飽 和ポリエステルグラフトカーボンブラックは, 過酸化ベ ンゾイルなどを用いて，スチレンなどのモノマーで架橋 でき，カーボンブラックが化学結合で組み込まれた深黒 色の半導電性樹脂が得られる。

Table 6 Grafting of polyesters onto carbon fiber by the copolymerization of epoxides with cyclic acid anhydrides ${ }^{\mathbf{a}}$.

\begin{tabular}{llccc}
\hline Epoxide & Anhydride & $\begin{array}{c}\text { Time } \\
(\mathrm{h})\end{array}$ & $\begin{array}{c}\text { Conversion } \\
(\%)\end{array}$ & $\begin{array}{c}\text { Grafting } \\
(\%)\end{array}$ \\
\hline SO & SAn & 48 & 30.5 & 20.9 \\
SO & MAn & 48 & 45.8 & 15.0 \\
SO & PAn & 48 & 58.1 & 17.5 \\
GPE & PAn & 96 & 38.3 & 6.3 \\
ECH & PAn & 48 & 45.6 & 39.5 \\
GMA & SAn & 48 & $52.7^{\mathrm{b}}$ & - \\
\hline
\end{tabular}

${ }^{\mathrm{a}}$ Carbon fiber, $0.20 \mathrm{~g}$; epoxide $=$ anhydride $=0.02 \mathrm{~mol}$; $N$-phenyl- $\beta$-naphthylamine, $0.02 \mathrm{~g} ; 18$-crown- $6,0.02 \mathrm{~g}$; $m$-xylene, $15.0 \mathrm{ml} ; 120^{\circ} \mathrm{C}$.

${ }^{b}$ Homopolymer of GMA.

(b) OLi 基を用いるアニオン重合

カーボンブラックやカーボンウイスカー表面の含酸素
官能基は， $n$-ブチルリチゥム (BuLi) で処理するてと により，OLi 基へと誘導できる(式 6 )。大北らは，カー ボンブラック表面の OLi 基は, $e$ 值が正のメタクリル酸 メチル (MMA) やアクリロニトリルのアニオン重合を開 始する能力があるととを見出した (式 26) ${ }^{33)}$ 。なお，ての ような系では，グラフト率は $100 \%$ を越える。

$n$
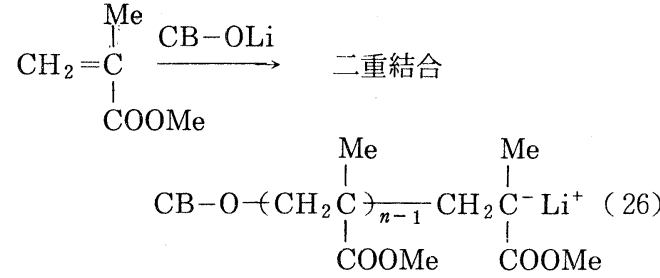

ところで，炭素材料表面の OLi 基には， $e$ 值が負のス チレンのアニオン重合を開始する能力はないが，ての系 ヘクラウンエーテルを加えて, OLi 基を活性化すると, スチレンや $\alpha$-メチルスチレンのグラフト重合あ可能に なり，グラフト率が 150 \%以上のあのが得られる ${ }^{34) 。 ~}$

さらに，OLi 基を用いてアクリルアミドの水素移動重 合を行うと,カーボンブラック表面からポリー $\beta$-アラ ニン (ナイロンー 3 ) がグラフトする $(\text { 式 } 27)^{35)}$ 。な抢，グ

$$
\begin{aligned}
& n \underset{\mathrm{CONH}_{2}}{\stackrel{\mathrm{CH}}{\mathrm{C}} \underset{120^{\circ} \mathrm{C}}{\longrightarrow}} \\
& \left.\mathrm{CB}-\mathrm{O}+\mathrm{CH}_{2} \mathrm{CH}_{2} \underset{\|}{\mathrm{C}}-\mathrm{NH}\right)_{n}
\end{aligned}
$$

ラフト率は $100 \%$ 近くのものが得られ, 反応生成物はポ リアミド中へ良く分散する性質を持つ。

(c) アミノ基による $\alpha$ 一アミノ酸 $N$ 一カルボン酸無 水物（NCA）の重合

カーボンヅラック表面のカルボキシル基を足場として $\mathrm{NH}_{2}$ 基を導入すると（式 10 )，粒子表面で $\alpha$ 一ミノ酸 $n$

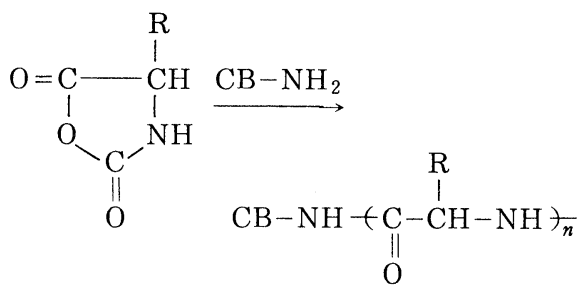

NCA の重合が開始され，ポリアミノ酸がグラフトする (式 28) ${ }^{36)}$ 。Table 7 には, 1 級, 2 級, 及び 3 級アミ， 基を導入したカーボンブラックによる $r$-メチルー $L$ グルタメートNCAのグラフト重合の結果を示した。重 合速度は， 1 級や 2 級アミノ基より， 3 級アミノ基の方 が大きい傾向を示すのに対して，カーボンブラック表面 
Table 7 Anionic graft polymerization of $\gamma$ methyl- $L$-glutamate NCA initiated by amino groups introduced onto carbon black surface.

\begin{tabular}{lccc}
\hline Carbon black & $\begin{array}{c}\text { Amino group } \\
(\mathrm{mmol} / \mathrm{g})\end{array}$ & $\begin{array}{c}\text { Conversion } \\
(\%)\end{array}$ & $\begin{array}{c}\text { Grafting } \\
(\%)\end{array}$ \\
\hline $\mathrm{CB}-\mathrm{NH}_{2}$ & 0.28 & 62.0 & 23.7 \\
$\mathrm{CB}-\mathrm{NH}_{2}$ & 0.23 & 35.6 & 17.4 \\
$\mathrm{CB}-\mathrm{NH}\left(\mathrm{CH}_{3}\right)$ & 0.20 & 52.4 & 19.6 \\
$\mathrm{CB}-\mathrm{N}\left(\mathrm{CH}_{3}\right)_{2}$ & 0.29 & 75.1 & 5.3 \\
\hline
\end{tabular}

Carbon black, $0.30 \mathrm{~g}$; NCA, $1.0 \mathrm{~g}$; dioxane, $20.0 \mathrm{ml}$; $30^{\circ} \mathrm{C} ; 96 \mathrm{~h}$.

へのポリアミノ酸のグラフト率は，3 級アミノ基の系が 一番小さい。乙れは，1級アミノ基の系では，アミノ基 の NCA への求核攻撃により重合が開始され，粒子表面 からポリアミノ酸の生長が起てるのに対して，3 級アミ ノ基の系では，アミノ基による NCA からの水素引抜き 反応で生成する NCA アニオンによって，ホモ重合が開 始されるため, グラフト率は小さくなるものと考えられ る。

なお，乙のようなポリアミノ酸グラフト炭素材料の利 用分野の開拓は将来の問題であるが，炭素材料表面への 酵素固定や生体適合性複合材料への応用が考えられる。

\section{5. 炭素材料表面の縮合芳香族環を利 用する機能基の導入}

これまで炭素材料表面のカルボキシル基やフェノール 性水酸基を利用した機能基の導入について述べてきた。 しかし，アセチレンブラック，グラファイト，及び炭素 繊維などは, 表面カルボキシル基やフェノール性水酸基 の量が少ない（Table 1) ため，乙れまでに述べた反応 は特別の場合を除いて困難である。したがって，上記の 反応を行うためには, 表面芳香族環をあらかじめ処理し， 望む官能基を導入する必要がある。乙こでは，炭素材料 表面の芳香族環への機能基の導入反応（Fig.5）につい て述べる。

\section{1 芳香族環の酸化}

カーボンブラックや炭素繊維を硝酸で処理すると表面 芳香族環が酸化され，カルボキシル基やフェノール性水 酸基が導入できることは良く知られている(式 29)。Fig. 6 には, 炭素繊維を硝酸で処理したときの処理時間と力 ルボキシル基及びフェノール性水酸基導入量との関係を 示した。これから処理の初期に, フェノール性水酸基が 導入されるが，処理時間を延長するとフェノール性水酸 基が減少し, カルボキシル基が増加することがわかる ${ }^{37) 。 ~}$

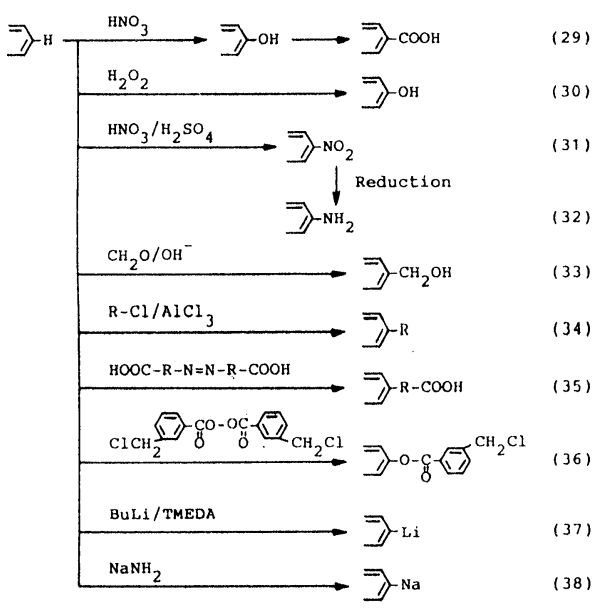

Fig. 5 Incorporation of functional groups onto aromatic rings of carbon materials.

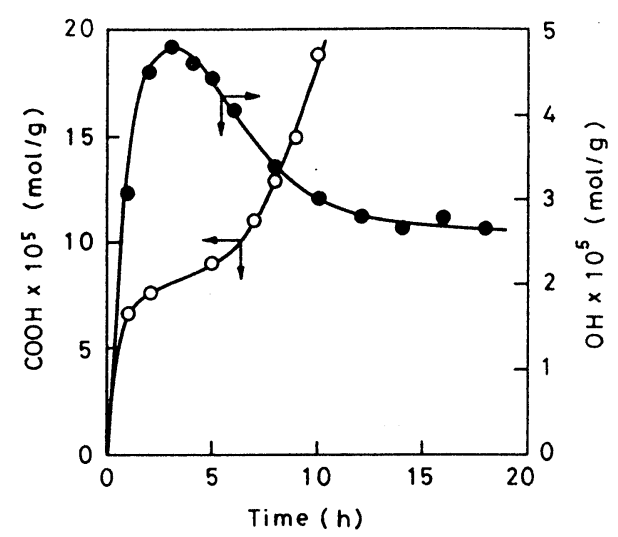

Fig. 6 The content of carboxyl and phenolic hydroxyl groups introduced onto carbon fiber by the treatment with nitric acid $(60 \%)$ at $100^{\circ} \mathrm{C}$.

また，炭素材料を酸素プラズマで処理するてとによっ てあ, カルボキシル基やフェノール性水酸基などの含酸 素官能基が芳香族環へ導入できる ${ }^{38) 。 ~}$

さらに, カーボンブラックを過酸化水素で処理すると 粒子表面へ優先的にフェノール性水酸基が導入できるこ と屯報告されている(式 30 ${ }^{39)}$ 。

\section{2 表面芳香族環への親電子置換反応}

\section{(a) 表面芳香族環のニトロ化}

芳香族化合物が親電子置換反応を受けることは良く知 られている。したがって, 炭素材料も各種の親電子試薬 
と反応することが期待できる。

たとえば，カーボンブラックやグラファイトを混酸や 発煙硝酸で処理すると, 表面芳香族環がニトロ化される

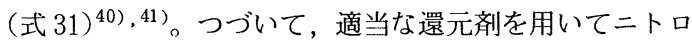
基を還元すると，粒子表面へアミノ基が導入できる（式 $32)^{41)}$ 。Table 8 には, 各種カーボンブラック表面への アミノ基の導入量を示した。さらに, Fig. 7 には，乙の ようなカーボンブラックによる，NCAの重合の結果を 示した。先に述べた方法では，カルボキシル基を持たな いカーボンブラックへのポリアミノ酸のグラフトは不可 能であったが，乙の方法を用いれば，カルボキシル基を 持たないカーボンブラック表面へもポリアミノ酸がグラ フトできる。

Table 8 Amino groups on carbon black surface introduced by the reduction of nitro groups.

\begin{tabular}{lcc}
\hline & \multicolumn{2}{c}{ Amino group (mmol/g) } \\
\cline { 2 - 3 } Carbon black & Nitrogen analysis & Titration by HC1 \\
\hline Neospectra II & 0.96 & 0.44 \\
Philblack O & 0.16 & 0.04 \\
Denkablack & 0.05 & 0.02 \\
\hline
\end{tabular}

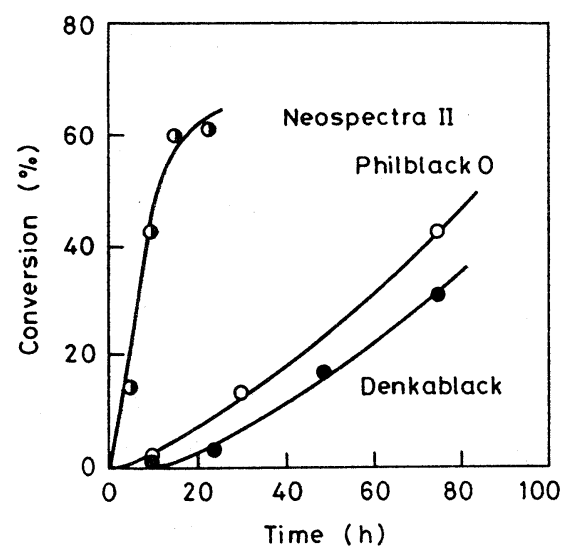

Fig. 7 Grafting of poly (amino acid) by the ring-opening polymerization of NCA initiated by amino groups on carbon black. Carbon black, $0.50 \mathrm{~g}$; NCA, 1.0 g; dioxane, $20.0 \mathrm{ml} ; 30^{\circ} \mathrm{C}$.

(b) 表面芳香族環のメチロール化

フェノール類のメチロール化之同様, フェノール性水 酸基を持つカーボンブラックを酸あるいは塩基触媒下で ホルムアルデヒドで処理すると, 表面芳香族環へメチロ
一ル基を導入することができる (式 33) ${ }^{42) 。}$

著者らは, メチロール基を導入したカーボンブラック と $\mathrm{Ce}^{4+}$ (酸化剤) とを組み合わせた系でアクリルアミド のラジカル重合が開始されることを見出した。このよう な重合系では， $\mathrm{Ce}^{4+}$ の作用で粒子表面に生成したメチ ロールラジカルからポリマーが生長するので（式 39）, 力 ーボンブラック表面へ効率良くポリアクリルアミドがグ ラフトする。

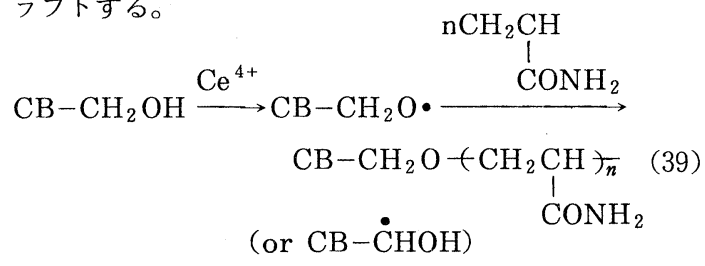

(c) 表面芳香族環へのフリーデルクラフト反応

最近，筆者らは炭素材料表面の芳香族環へのフリーデ ルクラフト反応が可能であることを見出した (式 34) ${ }^{43)}$ 。 すなわち，カーボンブラックに塩化アルミニウム触媒存 在下で，末端に酸クロリド基を持つポリエチレングリコ ール (PEG-COCl) を反応させると, 容易に粒子表面へ ポリマーがグラフトすることがわかった（式 40）。実験結 果の一例を Table 9 亿示した。

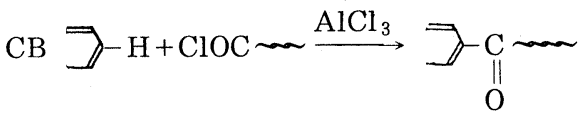

炭素材料表面の芳香族環へのフリーデルクラフト反応 はまだ末開拓の分野であり, 今後各種機能基の導入反応 へ利用できる可能性を秘めている。

Table 9 Grafting of acyl chloride-capped poly (ethylene glycol) by Friedel-Crafts reaction.

\begin{tabular}{lcc}
\hline Carbon black & $\begin{array}{c}\text { BET surface area } \\
\left(\mathrm{m}^{2} / \mathrm{g}\right)\end{array}$ & $\begin{array}{c}\text { Grafting } \\
(\%)\end{array}$ \\
\hline Neospectra II & 906 & 24.8 \\
FW 200 & 460 & 17.2 \\
Philblack O & 79.6 & 8.6 \\
Denkablack & 65 & 10.6 \\
\hline
\end{tabular}

Carbon black, $0.30 \mathrm{~g}$; PEG-COCl, $2.5 \mathrm{mmol}$; $\mathrm{AlCl}_{3}, 3.0 \mathrm{mmol}$; dioxane, $5.0 \mathrm{ml} ; 70^{\circ} \mathrm{C} ; 30 \mathrm{~h}$.

\section{3 表面芳香族環のラジカル捕捉性の利用}

多環芳香族化合物が遊離ラジカルと容易に反応するこ とが知られており，その反応性は，メチル親和力 ${ }^{44)}$ フェニル親和力 ${ }^{45)}$ で評価されている。カーボンブラッ クやグラファイトのメチル親和力は, ベンゼンの数百万 倍に達し，炭素材料が遊離ラジカルと活発に反応するこ 
とが予想できる。Donnet ら ${ }^{46)}$ や大北ら ${ }^{47)}$ は, カーボ ンブラックを 2,2 'ーアゾビスイソプチロニトリル (AIBN) や過酸化ベンゾイルで処理すると, 熱分解で生成する遊 離ラジカルが粒子表面へ結合することを報告している。

\section{(a) ラジカル反応による官能基の導入}

著者らは, カーボンブラックを反応性基を持つアゾ開始 剂で処理すると, 粒子表面へ容易に反応性基が導入でき ることを見出した。すなわち，カーボンブラックを4, 4’アゾビス (4-シアノペンタン酸) (ACP) で処理すると, $\mathrm{ACP}$ の熱分解で生成する4-シアノペンタン酸ラジカ ルが粒子表面へ結合する(式 35) ${ }^{48)}$ 。Fig. 8 には，ファ 一ネスブラックを ACP で処理したときの処理時間と力 ルボキシル基導入量との関係を示した。ACP 処理によ り, ファーネスブラック表面へ最高, $0.12 \mathrm{mmol} / \mathrm{g}$ の力 ルボキシル基が導入でき, しかも, 処理時間を変えるこ とによりカルボキシル基の導入量が容易に制御できるこ とがわかる。

な抢，乙のようにして導入したカルボキシル基を COOK 基に变換すると, エポキシドと環状酸無水物の開環交互 其重合による粒子表面へのポリエステルのグラフトが可 能になる (Table 10) ${ }^{48)}$ 。乙のような好理により，アセ チレンブラックやファーネスブラック表面へのポリエス テルのグラフトが初めて可能になった。

一方, カーボンブラックを 3,3 -ビスクロロメチルベ ンゾイルパーオキサイドで処理すると, 粒子表面へのク ロロメチル基の導入が可能である（式 36）。乙のような力

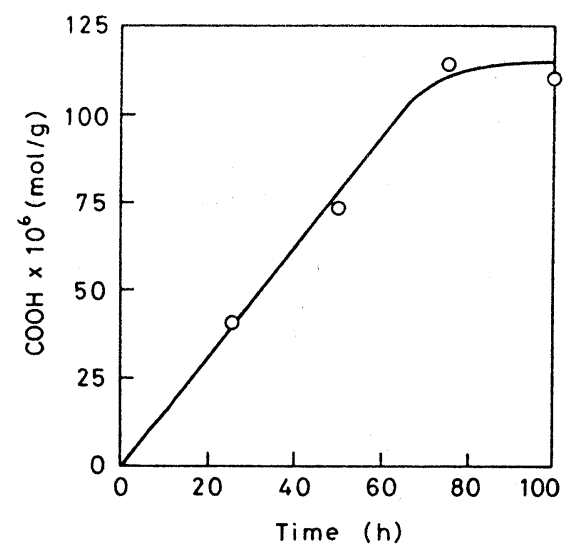

Fig. 8 The content of carboxyl groups introduced onto furnace black by the treatment with 4,4'-azobis (4-cyanopentanoic acid) (ACP).
Table 10 Anionic ring-opening copolymerization of epoxides with cyclic acid anhydrides initiated by COOK groups on Philblack O.

\begin{tabular}{lccc}
\hline Epoxide & Anhydride & $\begin{array}{c}\text { Conversion } \\
(\%)\end{array}$ & $\begin{array}{c}\text { Grafting } \\
(\%)\end{array}$ \\
\hline SO & PAn & 79.5 & 39.0 \\
SO & MAn & 65.2 & 37.4 \\
ECH & PAn & 77.1 & 40.0 \\
ECH & MAn & 63.0 & 35.1 \\
\hline
\end{tabular}

${ }^{\mathrm{a}}$ Carbon black, $0.30 \mathrm{~g}$; epoxide $=$ anhydride $=0.01 \mathrm{~mol}$; 18-crown-6, $0.02 \mathrm{~g} ; 120^{\circ} \mathrm{C}: 1 \mathrm{~h}$.

一ボンブラック表面では，2-オキサゾリンの開環重合 が開始され, 粒子表面から両親媒性のポリオキサゾリン がグラフトする(式 41) ${ }^{49) 。}$

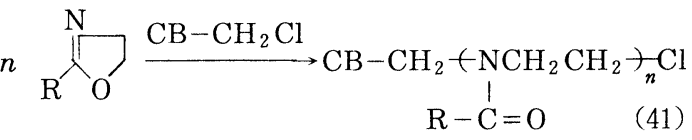

\section{(b) ポリマーラジカルとの反応}

上田らにより主鎖中にアゾ結合を持つ，いわゆるアゾ ポリマーの合成が報告されて扣り，ラジカル重合系に拉 けるブロックポリマーの给成に利用されている ${ }^{50), 51) 。 ~}$ 著者らは, 最近, アゾポリマーの熱分解で生成するポリ マーラジカルをカーボンブラックなどの炭素材料表面で 捕捉することによるグラフト反応について検討した（式 $42)^{52)}$ 。

$$
\begin{aligned}
& (\mathrm{OC}-\mathrm{R}-\mathrm{N}=\mathrm{N}-\mathrm{R}-\mathrm{CONH} \sim \mathrm{NH})_{n} \underset{n}{\stackrel{\Delta}{-\mathrm{N}_{2}}} \\
& \quad \text { Azo polymer }
\end{aligned}
$$

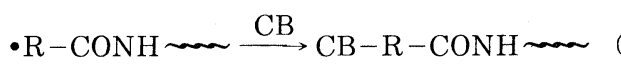

Fig. 9 には, シリコーンジアミンと 4, 4’ーアゾビス (4 ーシアノバレリン酸クロリド）との重縮合反応で合成し たアゾポリマー（数平均分子量, 3880）とカーボンブラ ックとの反応を行ったときの結果を示した。 $40{ }^{\circ} \mathrm{C}$ では, アゾポリマーの分解が起こらないために, グラフト反応 はほとんど進行しないが, $70 \sim 100^{\circ} \mathrm{C}$ で反応させると, 粒子表面へのポリマーのグラフト反応が起こる。

\section{4 縮合芳香族環のメタル化}

Donnet らは, カーボンブラックを $N, N, N^{\prime}, N^{\prime}$ - テ トラメチルエチレンジアミン (TMEDA)中, BuLi で処 理することにより縮合芳香族環をメタル化し (式 37,38$)$, これを触媒に用いてスチレンのアニオングラフト重合を 行った ${ }^{53)}$ 。

著者らも, この反応を炭素繊維やカーボンウイスカー 


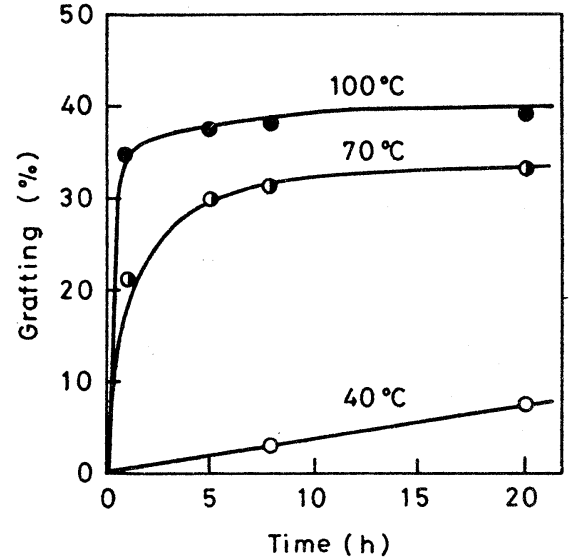

Fig. 9 Effect of temperature on the reaction of azo polymer with carbon black. Carbon black, $0.30 \mathrm{~g}$; azo polymer, $5.0 \mathrm{~g}$; toluene, $20.0 \mathrm{ml}$.

へ応用すると, 炭素緎維 ${ }^{54)}$ やカーボンウイスカー表面 ${ }^{55}$ へスチレンや MMA が効率良くグラフトできるととを見 出した（式 43）。Table 11 には, メタル化炭素繊維を用 $\left.n \stackrel{\mathrm{CH}_{2} \mathrm{CH}}{\underset{\mid}{\mathrm{X}}} \stackrel{\mathrm{CB}-\mathrm{Li}}{\longrightarrow} \mathrm{CB}+\mathrm{CH}_{2} \underset{\mid}{\mathrm{CH}}\right)_{n=1} \mathrm{CH}_{2} \mathrm{CH}^{-} \mathrm{Li}^{+}$

いるグラフト重合の一例を示した。非プロトン性極性溶 媒の TMEDAやへキサメチルホスホルトリアミド(HMPA) を用いた系では, 繊維表面のメタル化が起とり, 繊維表 面へポリマーがグラフトするが, THF やトルエンを溶 媒に用いると繊維表面のメタル化が起こらないため, グ ラフト反応は全く進行しない。

な抢，炭素繊維表面の酸化処理（カルボキシル基導入） を行うと繊維の強度が低下するという問題点があったが,

Table 11 Effect of solvent on the anionic graft polymerization initiated by metallized carbon fiber.

\begin{tabular}{llcc}
\hline Monomer & Solvent & $\begin{array}{c}\text { Conversion } \\
(\%)\end{array}$ & $\begin{array}{c}\text { Grafting } \\
(\%)\end{array}$ \\
\hline MMA & TMEDA & 20.8 & 35.5 \\
MMA & Toluene & 52.3 & 0 \\
MMA & THF & 71.1 & 0 \\
Styrene & TMEDA & 100 & 33.3 \\
MMA & HMPA & 6.2 & 40.9 \\
\hline
\end{tabular}

Pretreatment: Carbon fiber, $0.20 \mathrm{~g}$; solvent, $15.0 \mathrm{ml}$; $0^{\circ} \mathrm{C} ; 6 \mathrm{~h}$.

Polymerization:Monomer, $10.0 \mathrm{ml} ; 0^{\circ} \mathrm{C} ; 1 \mathrm{~h}$.
メタル化处理は, 炭素繊維の強度をほとんど低下させな いという特徴がある。

\section{6. 架橋（硬化）剤としての炭素材料}

すでに述べたように，炭素材料表面にはカルボキシル 基やフェノール性水酸基が存在し, 炭素材料は, 多価力 ルボン酸あるいは, 多価つェノールと類似の反応性を持 ち, 各種樹脂の硬化剂として作用する。

\section{1 ウレタンプレポリマーの架橋}

両末端にイソシアナート基を持つウレタンプレポリマ 一をカーボンブラックやカーボンウイスカーと加熱する とゲルが生成し，深黑色のエラストマーが得られる ${ }^{56) 。}$ Table 12 には, 各種のカーボンブラックとウレタンプレ ポリマー（数平均分子量，5100）との反応を行ったとき の結果を示した。Table 12 は，表面官能基の多いカー ボンブラック表面ほどゲル化能力が大きく，また本反応 は, トリエチルアミンの添加により促進されることを示 している。

なお，本反応で得られる生成物中には，カーボンブラ ック粒子が化学結合で組み込まれているので, 単にポリ ウレタン中へカーボンブラックを混練した物と比較して, 機械的性質などの向上が期待できる。

Table 12 Gelation of urethane prepolymer by various carbon blacks. ${ }^{\mathrm{a}}$

\begin{tabular}{|c|c|c|c|c|}
\hline \multirow[t]{2}{*}{ Carbon black } & \multirow{2}{*}{$\underset{(\mathrm{mmol} / \mathrm{g})}{\mathrm{COOH}}$} & \multirow{2}{*}{$\underset{(\mathrm{mmol} / \mathrm{g})}{\mathrm{OH}}$} & \multicolumn{2}{|c|}{ Gel fraction (\%) } \\
\hline & & & $\mathrm{I}^{\mathrm{b}}$ & $\mathrm{III}^{\mathrm{c}}$ \\
\hline None & - & - & 0 & 34.9 \\
\hline Philblack O & 0 & 0.02 & 22.4 & 44.5 \\
\hline Philblack I & 0 & 0.05 & 31.5 & 54.2 \\
\hline Neospectra II & 0.40 & 0.24 & 45.0 & 70.0 \\
\hline Carbolac 1 & 0.54 & 0.16 & 50.7 & 68.0 \\
\hline
\end{tabular}

${ }^{\mathrm{a}}$ Carbon black, $0.50 \mathrm{~g}$; urethane prepolymer $(\mathrm{Mn}=5100)$, $5.0 \mathrm{~g} ; 130^{\circ} \mathrm{C} ; 10 \mathrm{~h}$.

${ }^{b}$ In the absence of catalyst.

${ }^{c}$ In the presence of catalyst (triethylamine).

\section{2 エポキシ樹脂の硬化}

カーボンブラックは，エポキシ樹脂の硬化剂としても 作用する ${ }^{57) 。 F i g .10 に ， カ ー ホ ゙ ン フ ゙ ラ ッ ク を エ ホ ゚ キ シ ~}$ 樹脂と混ぜ合わせ，加熱したときの加熱温度とゲル分率 との関係を示した。 $150^{\circ} \mathrm{C}$ での硬化反応は速く約 5 時間 で，硬化反応が完了する。な拉，カーボンブラック表面 のカルボキシル基を水酸化カリウムで処理するとエポキ シ樹脂の硬化能力が著しく増大する。乙れは，粒子表面 へ導入されたカルボキシラートアニオンやフェノラート 


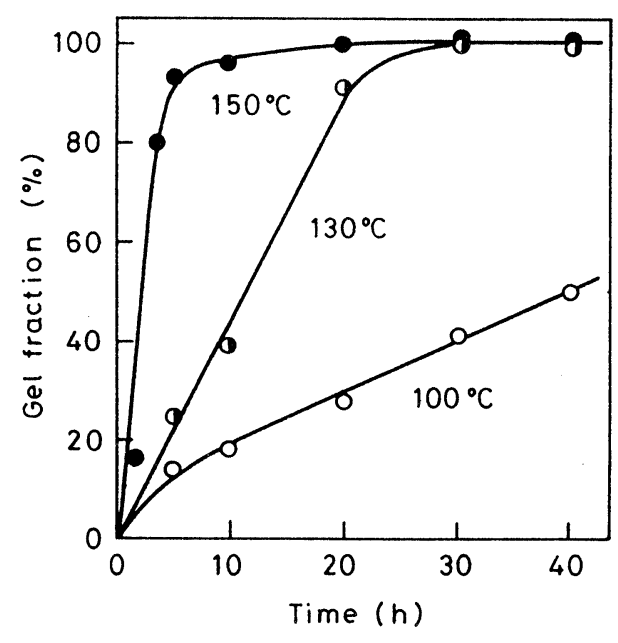

Fig. 10 Effect of temperature on the curing of epoxy resin (EP1004) by carbon black. Carbon black, $1.0 \mathrm{~g}$; epoxy resin, $5.0 \mathrm{~g}$.

アニオンがエポキシ環の開環反応をイオン的に進行させ るためと考えられる。

\section{3 多官能スピロオルトエステル類の硬化}

先にあ述べたように，カーボンブラックは，非収縮性 モノマーとして知られているSOE類のカチオン異性化 重合の触媒として作用する。一方, 多官能 SOE 樹脂は 酸無水物や酸触媒により硬化し, しか屯硬化時に体積収 縮を伴わないという特徵を持っている ${ }^{58)}$ 。

著者らは, カーボンブラックが多官能 SOE 樹脂の硬 化剂として作用することを見出した ${ }^{59)}$ 。Fig. 11 亿は， SOE 樹脂 (EXP 101 (式 44): 東要合成化学工業(株))を<smiles>CC(C)(C=COCC1COC(C)(C)O1)COCC1COC2(CCCO2)O1</smiles>

EXP 101

カーボンブラックと加熱したときの結果を示した。カー ボンブラックの存在しない系では SOE 樹脂の硬化反応 が全く進行しないのに対して, カーボンブラックの存在 下では, 深黒色の硬化物が得られる。

なお，乙のような SOE 樹脂硬化物中には，カーボン ブラックが化学結合で組み込まれており, しかむ硬化時 に体積収縮をほとんど起こさないので, 今後, 応用面の 展開が期待できる。

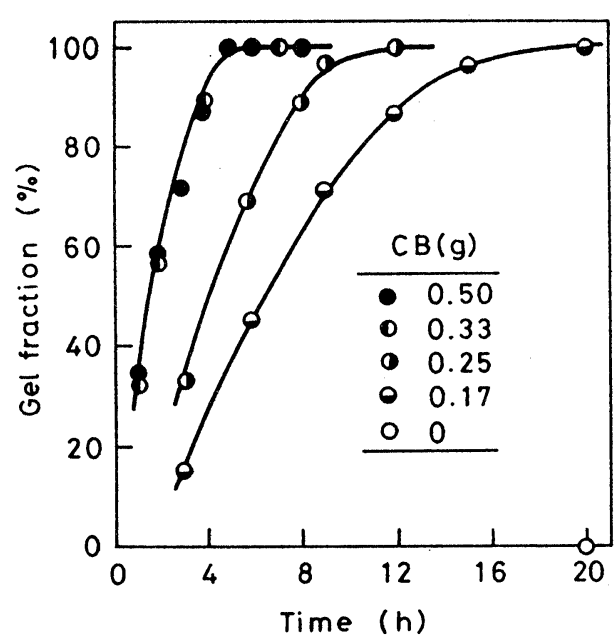

Fig. 11 Curing of SOE resin (EXP 101) by carbon black. EXP $101,1.0 \mathrm{~g} ; 150^{\circ} \mathrm{C}$.

\section{7. 電子伝達触媒としての炭素材料}

カーボンブラックは，ヒドラゾニトリル類のへキサシ アノ鉄 (III) 酸カリウムによる 2 相 (水相一有機相) 酸化 反応において電子伝達触媒として作用する ${ }^{60)}$ 。すなわち, 有機相のヒドラゾニトリルと水相のへキサシアノ鉄 (III) 酸カリウムを混合するだけでは，ヒドラゾニトリルの酸 化反応は進行しないが，乙の系へカーボンブラックを添 加すると, ヒドラゾニトリルの酸化反応が進行する。乙 のような反応系では, 副反応を伴うことなく高収率で対 応するアゾニトリル化合物が得られる (Table 13)。

これは, Fig. 12 に示したように, まず, カーボンブ ラック粒子表面のフェノール性水酸基が水相で酸化され フェノキシラジカルとなり, これが有機相へ移動して, ヒドラゾニトリル化合物を酸化するととすに，フェノー ル性水酸基が再生されるというサイクルを繰り返しなが

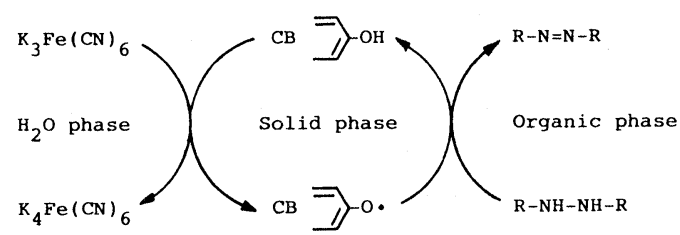

Fig. 12 Two-phase dehydrogenation of hydrazo nitriles using carbon black as electron transfer catalyst. 
Table 13 Two-phase dehydrogenation of hydrazo nitriles by the use of carbon black as the electron transfer catalyst.

\begin{tabular}{|c|c|c|c|}
\hline $\begin{array}{l}\text { Hydrazo } \\
\text { nitrile }\end{array}$ & $\begin{array}{c}\text { Carbon black } \\
(\mathrm{g})\end{array}$ & $\begin{array}{l}\text { Temperature } \\
\text { ( } \mathrm{C})\end{array}$ & $\begin{array}{c}\text { Azo nitrile } \\
(\%)\end{array}$ \\
\hline$\underset{\sim}{1}$ & - & 40 & 9.5 \\
\hline$\underset{\sim}{1}$ & 0.5 & 40 & 99.0 \\
\hline$\underset{\sim}{2}$ & - & 40 & 18.1 \\
\hline$\underset{\sim}{2}$ & 0.5 & 40 & 99.5 \\
\hline 3 & - & 40 & 80.0 \\
\hline 3 & 0.5 & 40 & 99.5 \\
\hline$\underset{\sim}{4}$ & - & 30 & 63.6 \\
\hline$\underset{\sim}{4}$ & 0.5 & 30 & 100 \\
\hline$\underset{\sim}{5}$ & - & 30 & 50.2 \\
\hline$\underset{\sim}{\sim}$ & 0.5 & 30 & 99.0 \\
\hline I & $\mathrm{R}=\alpha_{\mathrm{CN}}$ & $\mathrm{Me}_{\mathrm{N}} \mathrm{Me}^{\mathrm{CN}}$, isc & ${ }^{e} \mathrm{CN}, \mathrm{Ph}$ \\
\hline
\end{tabular}

ら進行するためと考えられている。なお，カーボンブラ ックのとのような電子伝達触媒としての能力は, 粒子表 面へ新たにフェノール性水酸基を導入 (式 30 ) すると著 しく増大する。

\section{8. 表面修飾炭素材料の特性}

\section{1 ポリマーグラフト炭素材料}

\section{(a) 分散安定性の向上}

既に述べたように，カーボンブラックやグラファイト 微粒子表面へポリマーをグラフトすると有機溶媒（グラ フト鎖の良溶媒）やポリマー中への分散性（易分散性及 び分散後の安定性）が著しく向上する。乙れは，粒子間 の反発力が高まるとともに，ポリマーあるいは分散媒中 への親和力が増大するためである。Fig. 13 には, PPG あるいはポリエステル（ポリー $\beta$ ープロピオラクトン） をグラフトしたカーボンブラックの THF 中への分散安 定性を未処理のあのと比較して示した。未処理のあのは, 短時間のうちに沈降してしまうのに対して, ポリマーを グラフトしたカーボンブラックは安定に分散し，上くに， グラフト率の大きなポリエステルグラフトカーボンブラ ックは, 室温で長時間放置しても沈降する粒子はわずか である。

(b) ポリマー中への均一分散

ポリマーをグラフトした炭素材料は, 未処理のものに 比較してポリマー中へ多量に配合でき, しかあ製品の強 度をあまり低下させないという特徴がある ${ }^{61)}$ 。その一例 として, Table 14に, ポリスチレンのトルエン溶液にグ ラフト率の異なるポリスチレングラフトカーボンブラッ クを配合してフィルムを作成し, その引っ張り強度を比

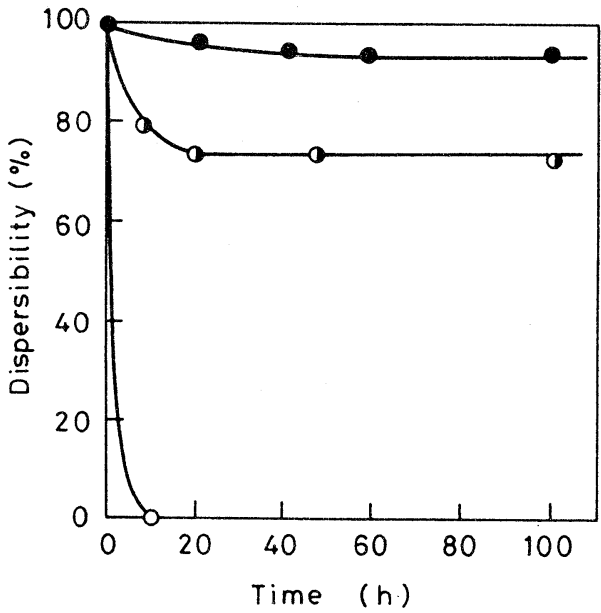

Fig. 13 Stability of dispersion of polymergrafted carbon black in THF.

-, polyester-grafted (grafting $=155 \%$ ); -, PPG-grafted (grafting $=27 \%$ ); $\bigcirc$, untreated.

Table 14 Tensile strength of polystyrene film mixed with polystyrene-grafted carbon black.

\begin{tabular}{lccc}
\hline Carbon black & $\begin{array}{c}\text { Grafting } \\
(\%)\end{array}$ & $\begin{array}{c}\text { Content of } \\
\text { carbon black } \\
(\text { wt\%) }\end{array}$ & $\begin{array}{c}\text { Tensile } \\
\text { strength } \\
\left(\mathrm{N} / \mathrm{mm}^{2}\right)\end{array}$ \\
\hline None & - & - & 26.2 \\
Untreated & 0 & 10 & 7.3 \\
Untreated & 0 & 20 & 5.3 \\
PS-grafted & 9.5 & 10 & 9.3 \\
PS-grafted & 9.5 & 20 & 7.4 \\
PS-grafted & 105.2 & 10 & 22.9 \\
PS-grafted & 105.2 & 20 & 18.1 \\
\hline
\end{tabular}

PS: Polystyrene

較した結果を示した。乙れから，高グラフト率のポリス チレングラフトカーボンブラックを配合したフィルムで はその強度低下は少ないととがわかる。乙れは，カーボ ンブラックがポリスチレン中へ均一に分散しているとと, 及びグラフト鎖とマトリックスとの相容性が優れている ことによるあのと考えられる。

(c) 炭素繊維とマトリックス樹脂との界面制御 炭素瀻維強化複合材料 (CFRP)の物性は, 炭素繊維之 マトリックス樹脂自体の特性ばかりでなく, 両者の界面の 影響を大きく受ける。すなわち，マトリックス樹脂から 
炭素瀻維に応力を伝達できるためには，炭素繊維と樹脂 との接着（濡机）性を向上させる必要がある。

四十容らは，ポリアクリル酸エステル類をグラフトし た炭素緘維とエポキシ樹脂とで作製したCFRPの引つ

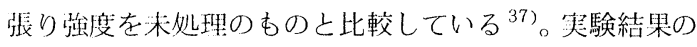
一例在 Fig. 14 亿示したが，ボリマーのグラフト率が大 きくなるととあに引っ䂻り虽度が堌大する。

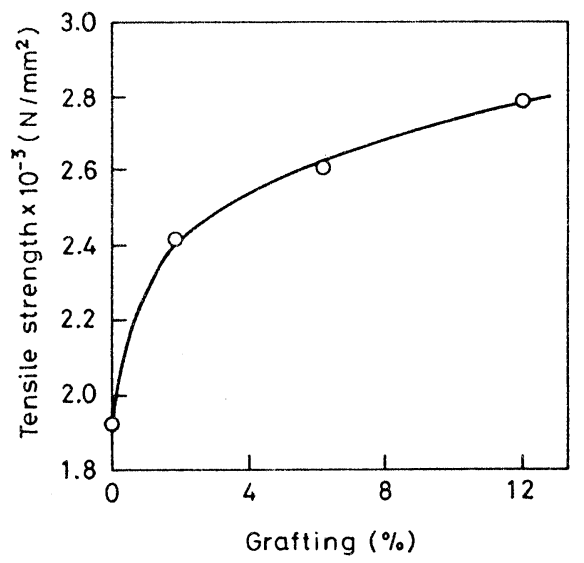

Fig. 14 Relationship between the tensile strength of composite consisting of epoxy resin and polymer-grafted carbon fiber and percentage of grafting.

\section{2 修飾電極}

これまで，炭素材料表面への機能基の導入とてれらを 用いたグラフト重合について概説したが, 最後に, 表面 修飾した炭素材料の機能性電極への応用について簡単に 述べる。

\section{(a) 不斉電解還元}

Miller らは, グラファイト電極表面へ導入した酸クロ リド基と $(S)-(-)$-フェニルアラニンメチルエステルと の反応により不斎電極を作成し，乙れを用いて，4-ア セチルピリジンやフェニルグリオキシル酸エチルの電 解還元を検討した ${ }^{62)}$ 。しかしながら, 不斉電極を用いる 電解合成に扔いては光学純度などの点で, 現在のとてろ まだ，十分な結果が得られていないのが現状のようであ る。

さらに，シクロデキストリンを結合させたグラファイ 卜電極を用いる芳香族化合物の位置選択的置換反応む榆 討されている ${ }^{63)}$ 。

\section{(b) 光応答性電極}

金子らは, トリス (2,2'ービピリジン) ルテニウム錯 体を含む高分子膜で被覆した炭素電極を作製し，メチル ビオロゲンを溶解した電解質溶液に浸し，てれに可視光 をあてると，光電流が流れるととを見出した ${ }^{64)}$ 。乙のよ うな, 炭素表面の高分子膜を介した電子移動反応に基づ く光応答炭素材料は, 上り効率の良い光反応系之炭素材 料表酒の精密な設計により，太晹電池へ之展開する叮能 性を秘めて抢り，興味があたれている。

\section{9. おわりに}

炭素材料として, カーボンブラック, グラファイト, 及び炭素緘維などへのポリマーのグラフトを目差した表 面機能化を中心にまとめた。乙てでは, 省略したが, 炭 素材料の機能化によるバイオテクノロジーへの応用 ${ }^{65}$ や新型電池用電極材料の開発 ${ }^{66)}$ も行われ，また，様々な インターカーラントを用いたグラファイト層間化合物 ${ }^{67)}$ あ炭素材料への機能付与ということで注目されている。

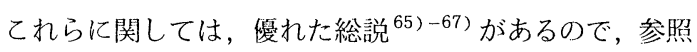
されたい。

また最近, カーボンペーパー, アモルファスカーボン, 等方性カーボン, さらには, 活性炭瀻維などの, いわゆ るニューカーボンが話題になっている。現在のとてろ, これらのニューカーボンの表面機能化については, 全く 未開拓の分野であるが, こてで述べた炭素材料の機能化 技術をニューカーボンへあ適用するてとにより，ニュー カーボンの優れた特性を著しく向上させた, 新しい素材 の開発む可能になるであろう。

\section{文献}

1) 稲垣道夫, 日ゴム協誌 61, 654 (1988)

2) カーボンブラック協会編, “カーボンブラック便覧”, 図書出版社 (1971) p. 183

3) N. Tsubokawa, K. Kobayashi and Y. Sone, J. Polym. Sci., Polym. Chem. Ed. 26, 223 (1988)

4) N. Tsubokawa, K. Kobayashi and Y. Sone, Polym. Bull. 13, 215 (1985)

5) N. Tsubokawa, K. Kobayashi and Y. Sone, Polym. Bull. 17, 87 (1987)

6) N. Tsubokawa, A. Kuroda and Y. Sone, J. Polym. Sci., Polym. Chem. Ed. 27, 1701 (1989)

7) N. Tsubokawa, A. Kuroda and Y. Sone, Polym. J. 20, 721 (1988)

8) 坪川紀夫, 細矢 学, 曽根康夫, 日本化学会第58 
春季年会講演要旨集 II，1078 (1989)

9) 大北熊一, “カーボンブラックのグラフト化”, ラ バーダイジェスト社 (1983) p. 52

10) R. Yosomiya and T. Fujisawa, Polym. Bull. 13, 7 (1985)

11) N. Tsubokawa, K. Fujiki and Y. Sone, Polym. J. 20, 213 (1988)

12) K. Ohkita, N. Tsubokawa, E. Saitoh, M. Noda and T. Takashima, Carbon 13, 443 (1975)

13) 藤木一浩，坪川紀夫，曽根康夫，炭素， 1989 [No. 140] p. 234

14) 坪川紀夫，藤木一浩，兽根康夫，Polym. Preprints, Japan 35, 300 (1978)

15) P.H. Given and L.W. Hill, Carbon 8, 525 (1968)

16) K. Ohkita, N. Tsubokawa, M. Noda and M. Uchiyama, Carbon 15, 194 (1977)

17) N. Tsubokawa, N. Takeda and A. Kanamaru, J. Polym. Sci., Polym. Lett. Ed. 18, 625 (1980)

18) N. Tsubokawa, N. Takeda and T. Iwasa, Polym. J. 13, 1093 (1981)

19) N. Tsubokawa, H. Maruyama and Y. Sone, J. Macromol. Sci.-Chem. A25, 171 (1988)

20) N. Tsubokawa, S. Ohshima, Y. Sone and T. Endo, J. Polym. Sci., Polym. Chem. Ed. 25, 935 (1987)

21) N. Tsubokawa, S. Ohshima, Y. Sone and T. Endo, Polym. J. 20, 413 (1988)

22) N. Tsubokawa, S. Ohshima, Y. Sone and T. Endo, J. Polym. Sci., Polym. Chem. Ed. 印刷中.

23) N. Tsubokawa, I. Asano and Y. Sone, Polym. Bull. 18, 377 (1987)

24) N. Tsubokawa, J. Polym. Sci. Polym. Chem. Ed. 22, 1515 (1984)

25) N. Tsubokawa, J. Appl. Polym. Sci. 30, 2041 (1985)

26) N. Tsubokawa, H. Nunokawa and Y. Sone, J. Macromol. Sci.-Chem. A23, 105 (1986)

27) N. Tsubokawa, Yu Jian and Y. Sone, $J$. Polym. Sci., Polym. Chem. Ed. 26, 2715 (1988)

28) N. Tsubokawa, J. Polym. Sci., Polym. Chem. Ed. 25, 1979 (1987)

29) N. Tsubokawa, A. Funaki, Y. Hada and Y. Sone, J. Polym. Sci., Polym. Chem. Ed. 20, 3297 (1982)
30) N. Tsubokawa, A. Yamada and Y. Sone, Polym. Bull. 10, 63 (1983)

31) N. Tsubokawa, H. Hamada and Y. Sone, Polym.-Plast. Technol. Eng. 28, 201 (1989)

32) 坪川紀夫, 吉原俊夫, 未発表.

33) K. Ohkita, N. Nakayama and T. Ohtani, J. Coatings Technol. 55, 35 (1983)

34) N. Tsubokawa, J. Macromol. Sci.-Chem. A24, 768 (1987)

35) N. Tsubokawa, Y. Nagano and Y. Sone, Polym. Bull. 10, 404 (1983)

36) N. Tsubokawa, K. Kobayashi and Y. Sone, Polym. J. 19, 1147 (1987)

37) A. Tanaka, T. Fujisawa and R. Yosomiya, J. Polym. Sci., Polym. Chem. Ed. 18, 2267 (1980)

38) 井原辰彦, 伊藤征司郎, 桑原利秀, 木卜光夫, 色材 56, 301 (1983)

39) 大北熊一，大谷 寛，日ゴム協誌 30, 14 (1957)

40) M. Fujihira, A. Tamura and T. Osa, Chem. Lett. 1977, 361

41) 坪川紀夫, 真柄和朗, 兽根康夫, Polym. Preprints Japan 36, 1487 (1987)

42) 坪川紀夫, 藤木一浩, 未発表

43) 坪川紀夫, 細矢 学, 未発表

44) M. Levy and M. Szwarz, J. Chem. Phys. 22, 1621 (1954)

45) D. Hey and G. Williams, Discuss. Faraday Soc. 14, 216 (1953)

46) J.B. Donnet, G. Henrich and L. Geldreich, Compt. Rend. 249, 97 (1959)

47) 大北熊一, 笠原博信, 石付範夫, 板垣義郎, 日ゴム 協誌 30, 361 (1963)

48) 坪川紀夫, 真柄和朗, 曽根康夫, 日ゴム協誌 62, 668 (1989)

49) N. Tsubokawa, Polym. Bull. 22, 55 (1989)

50) A. Ueda and Nagai, J. Polym. Sci., Polym. Chem. Ed. 24, 405 (1986)

51) H. Inoue, A. Ueda and S. Nagai, J. Polym. Sci., Polym. Chem. Ed. 26, 1077 (1988)

52) 梁取和人, 坪川紀夫, 兽根捸夫, Polym. Preprints Japan 38, 344 (1989)

53) J.B. Donnet, G. Riess and G. Majowski, Eur. Polym. J. 7, 1069 (1971)

54) 浜田広志, 坪川紀夫, 畺根康夫，第7回無機高分子 研究討論会講演要旨集 1988 , p. 41

55) 吉原俊夫, 坪川紀夫, 兽根康夫, Polym. Preprints Japan 38, 345 (1989)

56) 坪川紀夫, 才川信也, 曾根康夫, 高分子論文集 40 , 
753 (1983)

57) 坪川糺大, 叹本 博, 兽根康夫, 高分子論文集, 41, 597 (1984)

$58)$ 遠藤 剛, 小笠原誉久, 熱硬化性樹脂 5,98 (1984)

59) N. Tsubokawa, S. Ohshima, Y. Sone and T. Endo, Polym. J. 18, 851 (1986)

60) N. Tsubokawa, N. Takeda and Y. Sone, Bull. Chem. Soc. Japan 55, 3541 (1982)

61) 坪川紀夫, 藤木一浩, 曾根康夫, 高分子論文集 44, 605 (1987)

62) B.F. Watkins, J.B. Behling, E. Kariv and
L.L. Miller, J. Am. Chem. Soc. 97, 3549 (1975)

63) T. Matsue, M. Fujihira, T. Osa, J. Electrochem. Soc. 126, 500 (1979)

64) M. Kaneko, A. Yamada, N. Ohya and S. Yamaguchi, Mackomol. Chem. Rapid Commun. 3, 769 (1982)

65) 小島 昭, 炭素 1987 [No. 131] 199

66) 小沢丈夫, 炭素 1985 [No. 123] 180

67) 稲垣道夫, 村松一生, 炭素 1986 [No. 127] 196 